\title{
Aveia Preta, Triticale e Centeio em Mistura com Azevém. 1. Dinâmica, Produção e Qualidade de Forragem ${ }^{1}$
}

\author{
Cledson Roso², João Restle ${ }^{3}$, André Brugnara Soares ${ }^{4}$, Evelise Andreatta ${ }^{5}$
}

\begin{abstract}
RESUMO - O objetivo do experimento foi avaliar a dinâmica, produção e qualidade de forragem das misturas de aveia preta + azevém (MAA), triticale + azevém (MTA), centeio + azevém (MCA) em pastejo contínuo. Foram usadas bezerras com sete meses de idade inicial e $140 \mathrm{~kg}$ PV inicial. A semeadura foi realizada, a lanço, em 12 de abril de 1996, com $85 \mathrm{~kg} / \mathrm{ha}$ de aveia preta, $170 \mathrm{~kg} / \mathrm{ha}$ de triticale, 140 $\mathrm{kg} / \mathrm{ha}$ de centeio e $30 \mathrm{~kg} / \mathrm{ha}$ de azevém, nas respectivas misturas. A área foi adubada com $200 \mathrm{~kg} / \mathrm{ha}$ da fórmula 05-20-20 e a adubação nitrogenada foi de $220 \mathrm{~kg} / \mathrm{ha}$ de nitrogênio. O pastejo ocorreu no período de 21/05/96 a 19/11/96, na MAA e MCA, e de 04/06/96 a 19/11/96, na MTA. Houve interação entre tratamento e período de pastejo para as variáveis DIVMO e porcentagem de MS no resíduo. A taxa de acúmulo diário de MS e a produção total de MS não diferiram entre as misturas, apresentando produção de 9715 , 9752 e 9770 $\mathrm{kg}$ de MS/ha, respectivamente. A mistura MCA apresentou maior produção de MS logo após o estabelecimento e a MAA, nos períodos iniciais de pastejo; já a MTA apresentou melhor distribuição da produção de forragem durante o período de pastejo. Houve maior contribuição inicial do centeio no resíduo, seguido pela aveia preta e pelo triticale.
\end{abstract}

Palavras-chave: componente botânico, gramíneas, pastejo, potencial de produção

\section{Oat, Triticale and Rye in Mixture with Ryegrass. 1. Dynamics, Forage Yield and Quality}

ABSTRACT - The objective of the experiment was to evaluate the dynamics, forage yield and quality of the mixtures of oat + ryegrass (MOR), triticale + ryegrass (MTR), rye + ryegrass (MRR) in continuous grazing. Beef heifers with seven months of age and initial $140 \mathrm{~kg}$ LW were used. The sowing was broadcast at $04 / 12 / 96$, using $85 \mathrm{~kg} / \mathrm{ha}$ of oat, $170 \mathrm{~kg} / \mathrm{ha}$ of triticale, $140 \mathrm{~kg} / \mathrm{ha}$ of rye and $30 \mathrm{~kg} / \mathrm{ha}$ of ryegrass, in the respective mixtures. The area was fertilized with $200 \mathrm{~kg} / \mathrm{ha}$ of $05-20-20$ and the nitrogen fertilization was of $220 \mathrm{~kg} / \mathrm{ha}$ of nitrogen. The grazing period was from 05/21/96 to 11/19/96 in MOR and MRR and from 06/04/96 to 11/19/96 in MTR. There were interaction between treatment and grazing period for in vitro organic matter digestibility (IVOMD) and percentage of dry matter (DM) in the residue. The accumulation rate and total yield of DM did not differ among the mixtures, presenting a yield of 9,715, 9,752 and 9,770 kg/ha, respectively. The mixture MRR presented higher yield of DM just after the establishment and the MOR at the initial grazing periods, while the MTR presented better distribution of the forage yield during the grazing period. There was higher initial contribution of rye in the residue, followed by oat and triticale.

Key Words: botanical component, grasses, grazing, yield potential

\section{Introdução}

A base da alimentação da pecuária de corte no Rio Grande do Sul continua sendo o campo nativo, que é composto basicamente por espécies de crescimento estival, apresentando elevada produção de forragem no verão, paralisação do crescimento e queda na qualidade da forragem no outono-inverno. A estacionalidade na produção de forragem causa déficit alimentar para os bovinos de corte no outonoinverno, constituindo-se um dos principais entraves para a elevação dos índices produtivos do rebanho bovino. A utilização de gramíneas anuais de estação fria como pastagem é uma alternativa que pode ser usada para suprir o déficit alimentar deste período. Além disso, as pastagens cultivadas de inverno são alternativas para rotação com as culturas de verão, pois o Rio Grande do Sul apresenta uma área de aproximadamente 5 milhões de hectares cultivados com soja e milho, dos quais apenas $12 \%$ são utilizados para o plantio do trigo, sendo o restante da área mal aproveitado no inverno (IBGE, 1996).

Resultados de pesquisa com aveia preta mais azevém têm demonstrado o elevado potencial para produção de forragem destas espécies, na condição de pastejo (LUPATINI et al., 1998; RESTLE et al.,

\footnotetext{
1 Trabalho extraído da dissertação de mestrado do primeiro autor.

2 Eng ${ }^{\circ}$. Agrônomo, Mestre em Zootecnia.

${ }^{3}$ Eng. Agro ${ }^{\circ}$ Ph.D., Professor Titular, Bolsista do CNPq, Departamento de Zootecnia da UFSM, CEP: 97119-900 - Santa Maria - RS

${ }^{4}$ Eng. Agro ${ }^{5}$ Aluno do Curso de Pós Graduação em Zootecnia, UFSM.

${ }^{5}$ Aluna do Curso de Medicina Veterinária, UFSM.
} 
1998). No entanto, a mistura tem apresentado má distribuição da produção de forragem ao longo do período de utilização. Outras espécies de gramíneas anuais de estação fria são alternativas que podem ser utilizadas em misturas com o azevém, como o triticale e o centeio.

O triticale tem demonstrado resultados promissores na produção de grãos e forragem em algumas regiões do Rio Grande do Sul e do Paraná, destacando-se pela sua rusticidade e produtividade (BAIER, 1989; B AIER et al., 1994). O centeio destaca-se pelo crescimento inicial vigoroso, pela rusticidade e pela resistência ao frio, à seca e à acidez do solo (BAIER, 1994). No entanto, são raras as informações sobre a distribuição da produção, produção e qualidade de forragem do triticale e centeio em misturas com o azevém, principalmente na condição de pastejo no Rio Grande do Sul.

As misturas forrageiras visam antecipar e aumentar o período de utilização das pastagens, além de manter a estabilidade na produção e qualidade de forragem. No entanto, para que uma mistura seja eficiente, é necessário que uma espécie não prejudique o desenvolvimento da outra, em termos de luminosidade ou nutrientes, para que a produtividade das espécie seja maximizada dentro da mistura.

O objetivo deste trabalho foi avaliar a aveia preta, o triticale e o centeio em mistura com o azevém, quanto à distribuição da produção, produtividade e qualidade de forragem em pastejo contínuo.

\section{Material e Métodos}

O experimento foi conduzido no período de abril a novembro de 1996, na área experimental do Departamento de Zootecnia da Universidade Federal de Santa Maria, situada na Depressão Central do Rio Grande do Sul, à altitude de $95 \mathrm{~m}$, latitude $29^{\circ} 43^{\prime}$ sul e longitude $53^{\circ} 42^{\prime}$ oeste. O solo da área experimental é classificado como Podzólico Vermelho-Amarelo. $\mathrm{O}$ clima da região é Cfa (subtropical úmido), conforme classificação de Köppen (MORENO, 1961).

Foram avaliadas as misturas de Aveia preta (Avena strigosa Schreb) cv. comum + azevém (Lolium multiflorum Lam.) cv. comum (MAA), Triticale (X Triticosecale Wittmack) cv. CEP $23+$ azevém cv. comum (MTA), Centeio (Secale cereale L.) cv. BR 1 + azevém cv. comum (MCA).

A análise de solo da área experimental mostrou pH de 4,8, teor de fósforo de 20,4 (extração pelo método de Mehlich) e K de 94 mg/litro. A calagem foi realizada em dezembro de 1995 , utilizando-se 5 toneladas/ha de calcário dolomítico (PRNT 60\%), o que correspondeu a $70 \%$ da quantidade necessária para elevar o pH a 5,5, sendo incorporado no momento do preparo do solo para a instalação do experimento, por meio de aração, à profundidade de $15 \mathrm{~cm}$, seguida por gradagem leve.

A área experimental foi dividida em nove piquetes, totalizando 8,6 ha, mais uma área contígua de 8,5 ha para permanência dos animais reguladores.

A adubação de base foi realizada a lanço, após a aração, utilizando a quantidade recomendada para reposição, conforme as RECOMENDAÇÕES DE ADUBAÇÃO E CALAGEM PARA O RIO GRANDE DO SUL E SANTA CATARINA (1989). Na adubação, foram utilizados $200 \mathrm{~kg} / \mathrm{ha}$ da fórmula 05-20-20.

A semeadura foi a lanço no dia 12 de abril de 1996. As espécies foram semeadas individualmente, devido à diferença no peso específico das sementes, com o objetivo de uniformizar a semeadura. Logo após a semeadura, as sementes foram incorporadas com grade de dentes, a fim de se obter densidade próxima a 425 sementes viáveis $/ \mathrm{m}^{2}$ para a aveia preta, o triticale e centeio e 840 sementes viáveis $/ \mathrm{m}^{2}$ para o azevém. Para isso, foram utilizados $85 \mathrm{~kg} / \mathrm{ha}$ de aveia preta, $170 \mathrm{~kg} / \mathrm{ha}$ de triticale, $140 \mathrm{~kg} / \mathrm{ha}$ de centeio mais $30 \mathrm{~kg} / \mathrm{ha}$ de azevém, nas respectivas misturas.

O método de pastejo foi o contínuo com lotação variável, empregando a técnica de "Put and take"(MOTT e LUCAS, 1952). Para o pastejo, foram utilizadas bezerras de corte com idade média inicial de sete meses e peso vivo de $140 \mathrm{~kg}$. A oferta de forragem pretendida foi de $10 \%$ do peso vivo (10 $\mathrm{kg}$ de MS disponível para cada $100 \mathrm{~kg}$ de peso vivo/dia).

O delineamento experimental utilizado foi o inteiramente casualizado, com três repetições. Realizouse a análise de variância seguindo o modelo matemático abaixo:

em que

$$
Y_{i k j}=M+T_{i}+P_{k}+T_{i} P_{k}+E_{i k j}
$$

$\mathrm{Y}_{\mathrm{ikj}}=$ variável dependente;

$\mathrm{M}=$ média das observações;

$\mathrm{T}_{\mathrm{i}}=$ efeito $_{\mathrm{i}}$ do tratamento;

$\mathrm{P}_{\mathrm{k}}=$ efeito do ${ }_{\mathrm{k}}$ período;

$\mathrm{T}_{\mathrm{i}} \mathrm{P}_{\mathrm{k}}=$ efeito da interação entre $\mathrm{o}_{\mathrm{i}}$ tratamento com $\mathrm{o}_{\mathrm{k}}$ período; $\mathrm{e}$

$\mathrm{E}_{\mathrm{ikj}}=$ efeito do erro aleatório associado a cada observação.

Os dados foram analisados pelo método dos quadrados mínimos (SAS, 1990). Foi utilizado o teste de comparações de médias com base no método dos 
quadrados mínimos (Pdiff - SAS, 1990), em nível de $5 \%$ de significância.

A adubação nitrogenada aplicada em cobertura de $220 \mathrm{~kg}$ de N/ha, na forma de uréia, foi parcelada em quatro aplicações, realizadas nas seguintes datas: 23/06, 22/07, 18/08 e 29/09/96. A primeira aplicação deveria ter sido realizada no início de maio, mas foi retardada devido à estiagem ocorrida no período. As quantidades de nitrogênio constaram de $50 \mathrm{~kg} / \mathrm{ha}$ nas duas primeiras aplicações e $60 \mathrm{~kg} / \mathrm{ha}$ nas aplicações finais, observandose as condições agronômicas recomendadas para o melhor aproveitamento do nitrogênio.

A massa de forragem (MS) das pastagens foi avaliada a cada 28 dias, aproximadamente, retirandose dez amostras $\left(0,25 \mathrm{~m}^{2} /\right.$ amostra $)$ por piquete, as quais foram cortadas rente ao solo. A forragem proveniente das amostras cortadas foi homogeneizada e, posteriormente, duas amostras compostas foram retiradas. Uma amostra foi utilizada para a estimativa da composição botânica da pastagem e a outra amostra composta, para determinação da matéria parcialmente seca, a qual foi considerada como matéria seca. Todas as amostras foram secas em estufa a $65^{\circ} \mathrm{C}$. O teor de proteína bruta foi obtido pelo método micro Kjeldahl (AOAC, 1984) e a digestibilidade in vitro da matéria orgânica (DIVMO), por intermédio da determinação da digestibilidade in vitro da matéria seca e do teor de matéria orgânica (TILLEY e TERRY, 1963).

A estimativa da taxa de acúmulo diário de MS das misturas foi avaliada a cada 28 dias, aproximadamente, com o uso de três gaiolas de exclusão ao pastejo por unidade experimental, e, adotando o método do triplo emparelhamento, as amostras continham área de $0,25 \mathrm{~m}^{2}$. A taxa de acúmulo de MS do período foi estimada por intermédio da equação descrita por CAMPBELL (1966). A produção total de MS foi calculada pelo somatório das produções dos períodos (taxa de acúmulo diário x número de dias do período) mais a disponibilidade inicial de forragem.

A estimativa da produção de matéria seca, por espécie, foi obtida multiplicando a taxa de acúmulo de MS pelo percentual dos componentes botânicos dos resíduos, nos mesmos períodos, assumindo que as espécies apresentaram a mesma eficiência fotossintética. A estimativa do percentual de produção de MS por espécie foi obtida dividindo a produção das espécies em cada período pela produção total de matéria seca da mesma e multiplicado por 100.

A primeira avaliação da massa de forragem realizada no dia 16/05/96 resultou em valores de $819 \mathrm{~kg}$ de MS/ha na MAA, $838 \mathrm{~kg}$ de MS/ha na MTA e $1256 \mathrm{~kg}$ de MS/ha na MCA. Como na MAA e MCA já ocorria acamamento de plantas, optou-se pelo início do pastejo no dia 21/05/96. Na MTA, o início do pastejo ocorreu no dia 04/06/96, portanto, 14 dias mais tarde.

\section{Resultados e Discussão}

Houve déficit hídrico acumulado de 522 mm durante o período experimental (março a novembro) em relação à precipitação que normalmente ocorre; o maior déficit ocorreu nos meses de abril e maio (205 $\mathrm{mm}$ ), com precipitação normal de $348 \mathrm{~mm}$. A insolação ocorrida no período de abril e maio foi 43 horas superior à que normalmente ocorre (327 horas). Essa combinação de pouca precipitação e elevada insolação e altas temperaturas favoreceu a evapotranspiração, agravando o período de déficit hídrico.

A taxa de acúmulo diário de MS (Tabela 1) não apresentou interação significativa entre as misturas e os período de avaliação. Observa-se que as taxas de acúmulo de MS, na média das três misturas, foram menores nos períodos iniciais (21/05 a 23/07) e finais. Os baixos valores iniciais são atribuídos ao déficit hídrico ocorrido no período, e à não aplicação de nitrogênio no início do perfilhamento, em razão da falta de condições climáticas adequadas para o melhor aproveitamento do mesmo. Os maiores valores foram encontrados no quarto período (20/08 a 20/09), associados às condições climáticas favoráveis, temperatura mais elevada, aumento do fotoperíodo e solo com boa umidade, que favoreceram o crescimento do azevém. Estes resultados são semelhantes aos encontrados por LUPATINI et al. (1998), avaliando aveia preta + azevém.

As médias das taxas de acúmulo não apresentaram diferenças entre as misturas, com valores de 47,77; 48,12; e 45,92 kg de MS/ha॰dia, respectivamente, para MAA, MTA e MCA. Apesar de ter ocorrido pequena variação na taxa de acúmulo de MS, ao longo do período de pastejo, ocorreu compensação nas produções entre os períodos, chegando ao final do período de utilização da pastagem com taxas de acúmulo muito semelhantes.

Os resultados encontrados neste experimento são semelhantes aos obtidos por ROSO et al. (1999), para a mistura de triticale + azevém e inferiores aos obtidos na mistura de aveia preta + azevém, e inferiores aos obtidos por LUPATINI et al. (1998) e 
ROSO et al.

Tabela 1 - Taxa de acúmulo (kg de MS/ha•dia) e produção de forragem por período de avaliação na pastagem com misturas de gramíneas anuais de estação fria

Table 1 - Herbage accumulation rate ( $\mathrm{kg}$ of DM/ha•day) and forage yield in annual temperate grasses mixtures pastures during the experimental period

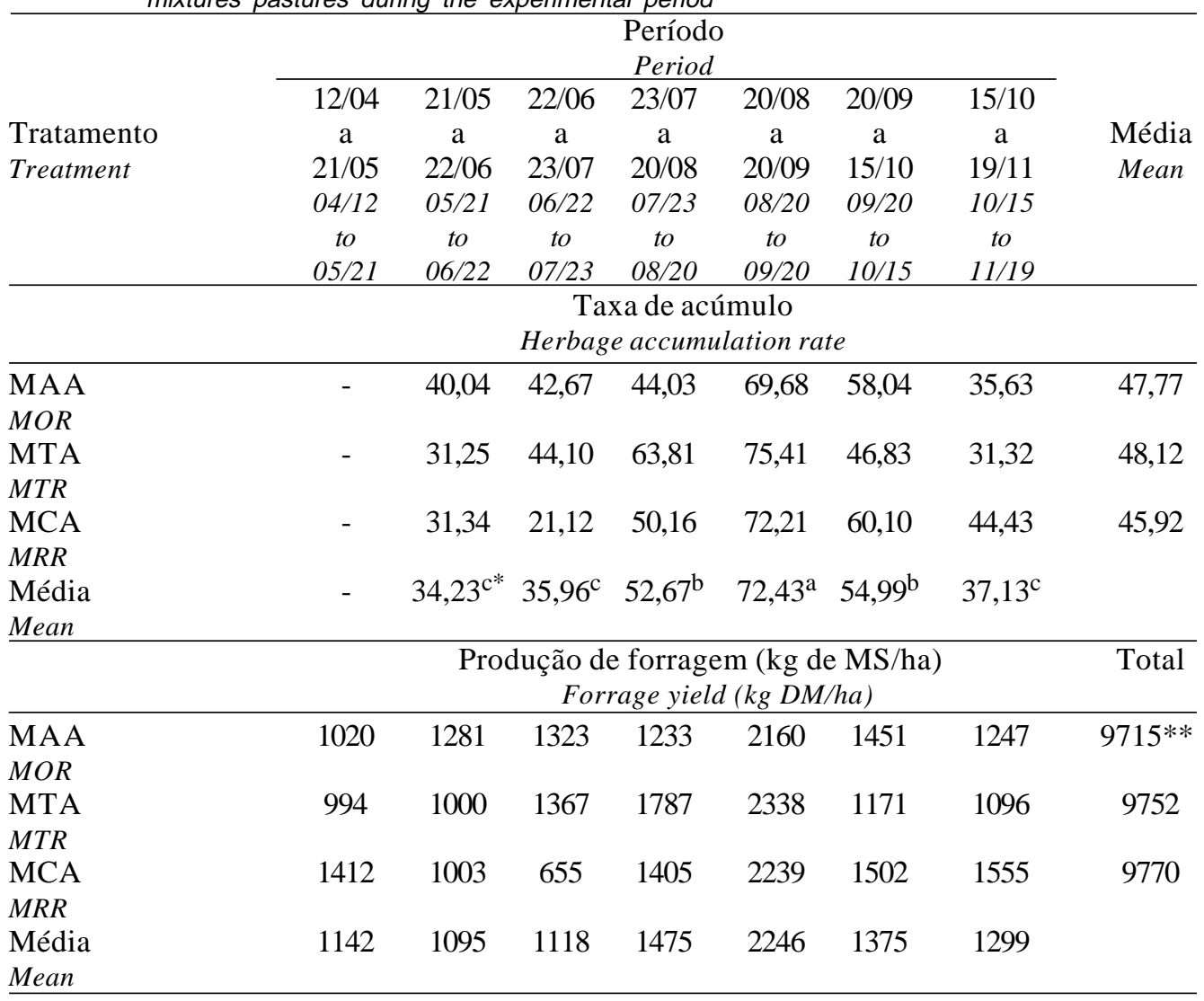

* a, b, c Médias seguidas por letras diferentes na mesma linha diferem $(P<0,05)$ pelo teste $t$.

* a, b, $c$ Means followed by different letters in the same line differ $(P<.05)$ by $t$ test.

** $\quad P>0,9985$

** $\quad P>9985$

RESTLE et al. (1998), com aveia preta + azevém (trabalhos realizados na área do presente experimento), e LESAMA (1997), que avaliou consorciações de aveia preta + azevém com nitrogênio e/ou trevo vesiculoso, no período de agosto a início de novembro. Os resultados do presente trabalho são também superiores aos valores obtidos por RESTLE et al. (1997), para a mistura de aveia preta + azevém. Provavelmente, esta menor taxa de acúmulo de MS obtida neste experimento, quando comparada com os trabalhos que usaram os mesmos níveis de fertilização em misturas com espécies semelhantes, deve-se ao longo período de utilização da pastagem, ocorrendo maior gasto de energia para a mantença do metabolismo (LEMAIRE, 1997), e também às baixas temperaturas e à pouca luminosidade do outonoinverno, que não favorecem a fotossíntese. Conseqüentemente, diminui-se a relação fotossíntese líquida/respiração, ocorrendo, também, maior fracionamento dos fertilizantes utilizados, principalmente o nitrogenado, ao longo do período de utilização da pastagem.
A produção total de MS (Tabela 1) não diferiu entre as misturas. A MCA, embora tenha apresentado menor taxa de acúmulo de MS $(\mathrm{P}>0,05)$ no período de pastejo (21/05 a 19/11), foi compensada pela maior produção no período da emergência até o início das avaliações, quando começou o pastejo (21/05), sendo sua disponibilidade inicial de $1412 \mathrm{~kg}$ de MS/ha. As produções totais foram de 9715,9752 e $9770 \mathrm{~kg}$ de MS/ha para MAA, MTA e MCA, respectivamente.

Os resultados encontrados mostram que as misturas apresentaram elevada produção de forragem, sendo semelhantes aos resultados obtidos por ROSO et al. (1999), que trabalharam com as misturas de azevém + aveia preta ou triticale, e LUPATINI et al. (1998), no mesmo nível de adubação nitrogenada. No entanto, são superiores aos obtidos por RESTLE et al. (1997), RESTLE et al. (1998) e LESAMA (1997), sendo que todos os autores acima trabalharam com a mistura de aveia preta + azevém.

As produções máximas obtidas neste experimento e por outros pesquisadores que utilizaram as mesmas 
misturas sob pastejo ficaram próximas a $10 \mathrm{t}$ de MS/ha.

O percentual da produção de forragem acumulada por componente (Tabela 2) mostra que o centeio apresentou maior precocidade de produção, sendo que no início da utilização da pastagem (21/05) ocorreu $30,3 \%$ de sua produção total de MS. Já aveia preta e o triticale apresentaram produções menores e semelhantes no início do pastejo. Da emergência até a avaliação de 18/06, a aveia preta e o centeio produziram 51,9 e $51,0 \%$ da sua produção total de forragem, respectivamente. A partir desta data, a aveia preta apresentou aumentos mais acentuados na produção total. Este menor aumento na produção do centeio, em comparação com a aveia preta, ocorreu devido à rápida produção inicial do centeio, com conseqüente elevação dos meristemas apicais, ou seja, o centeio apresentou maior precocidade de produção. $\mathrm{O}$ fato de não terem ocorrido baixas temperaturas durante o estabelecimento da pastagem fez com que o centeio elevasse seu ponto de crescimento sem muito perfilhamento, sendo que, aos 35 dias após a semeadura, esta espécie já estava emitindo as primeiras espigas. Com o início do pastejo, houve eliminação dos pontos de crescimento e senescência das plantas de centeio, havendo a formação de novos afilhos, acarretando em atraso na produção de forragem. Já o triticale apresentou menor produção inicial e melhor distribuição da produção de forragem ao longo do período de utilização. Os resultados obtidos são semelhantes aos encontrados por FONTANELI et al. (1996), que obtiveram maior produção de MS para o centeio em regime de cortes aos 60 dias, entretanto, no corte realizado 30 dias após o primeiro, a maior produção de MS foi verificada para o triticale. Já SÁ e OLIVEIRA (1995) obtiveram maior produção de MS para o centeio BR1 nos cortes aos 50, 70, 90 e 110 dias, seguidos pelo triticale IAPAR 23 e aveia preta comum. O azevém apresentou pequena produção inicial, sendo que os maiores valores ocorreram na mistura com triticale, seguido pela mistura com aveia preta, havendo menor participação inicial na mistura com o centeio, provavelmente devido à maior competição por luminosidade e nutrientes com esta espécie.

A maior produção de forragem do azevém no início do período de utilização da pastagem, obtida na mistura com o triticale em relação às demais misturas, também foi observada por ROSO et al. (1999), o que, provavelmente, se deve à maior penetração de luminosidade nos estratos inferiores da pastagem, favorecida pela presença de folhas mais eretas e colmos mais vigorosos do triticale que preveniram seu acamamento inicial. A pequena variação na produção de forragem do triticale nos períodos iniciais de pastejo e a maior contribuição inicial do azevém proporcionaram melhor distribuição da produção de forragem ao longo do período de pastejo, não havendo alternância de períodos com elevada e baixa produção de forragem.

O percentual dos componentes botânicos da disponibilidade de forragem das misturas é apresentado na Tabela 3. Observa-se que houve maior participação inicial do centeio, seguido pela aveia preta e triticale, que contribuíram com 91,$5 ; 83,3 ;$ e 75,3\%, respectivamente, das misturas com azevém. Estes resultados evidenciam a precocidade destas espécies e a sua contribuição na produção inicial de forragem, quando de suas associações com o azevém, que apresenta pequena participação inicial (ROSO et al., 1999). Em todas as misturas, houve decréscimo significativo destas espécies com o aumento do período de utilização, sendo que a aveia e o triticale desapareceram em 07/09 e o centeio, em 06/10. O centeio apresentou o maior decréscimo em junho, em virtude do rápido crescimento inicial e da elevação do meristema apical, com conseqüente corte pelo pastejo, propiciando maior estímulo à formação de novos afilhos e aumentando, com isso, o ciclo produtivo da espécie.

O maior percentual de material morto nos primeiros períodos de pastejo foi observado na MCA e o menor, na MTA. O elevado percentual de material morto verificado, principalmente na mistura com centeio, na avaliação de 13/07, ocorreu devido ao maior crescimento inicial e à rápida diferenciação floral do centeio, que, com o pastejo, teve seus meristemas apicais eliminados, acelerando a senescência das plantas e, também, devido ao maior acamamento ocorrido. Este fato confirma a afirmação de BAIER (1994) de que o centeio BR1 é suscetível ao acamamento, devido a seu porte alto. Já na MTA, não foi observado grande aumento no percentual de material morto até a avaliação de 07/09, em razão de as plantas de triticale terem apresentado colmos mais vigorosos, que dificultaram o acamamento inicial.

A massa de forragem das misturas é apresentada na Tabela 4, na qual se verificam valores inferiores no início do período de pastejo, com exceção da mistura com centeio, na qual ocorreu diminuição do primeiro para o terceiro período, devido ao rápido ciclo produtivo desta espécie e à diminuição acentuada na taxa de acúmulo. No início do período de pastejo, ocorreu crescimento rápido em altura e excessivo acúmulo de material verde na pastagem, acompanhado de 
ROSO et al.

Tabela 2 - Produção de forragem acumulada, em percentual, por espécies, de acordo com os períodos de avaliações na pastagem com misturas de gramíneas anuais de estação fria

Table 2 - Proportion (\%) of accumulated forage for species throughout the experimental period in annual temperate grasses mixtures pastures

\begin{tabular}{|c|c|c|c|c|c|c|c|c|c|}
\hline \multirow{6}{*}{$\begin{array}{l}\text { Trat. } \\
\text { Treat. } \\
\text { MAA } \\
\text { MOR }\end{array}$} & \multirow{3}{*}{$\begin{array}{l}\text { Componente } \\
\text { Component }\end{array}$} & \multicolumn{7}{|c|}{$\begin{array}{l}\text { Data da avaliação } \\
\text { Evaluation date }\end{array}$} & \multirow[b]{2}{*}{$19 / 11$} \\
\hline & & $21 / 05$ & $18 / 06$ & $13 / 07$ & $10 / 08$ & $07 / 09$ & $06 / 10$ & $03 / 11$ & \\
\hline & & $05 / 21$ & $06 / 18$ & $07 / 13$ & $08 / 10$ & $09 / 07$ & $10 / 06$ & $11 / 03$ & $11 / 19$ \\
\hline & Aveia & 24,7 & 51,9 & 73,5 & 88,0 & 96,9 & 100,0 & - & - \\
\hline & Oat & & & & & & & & \\
\hline & Azevém & 02,3 & 05,8 & 10,8 & 22,3 & 44,6 & 72,3 & 91,4 & 100,0 \\
\hline & Ryegrass & & & & & & & & \\
\hline MTA & Triticale & 22,9 & 43,0 & 62,7 & 83,5 & 96,3 & 100,0 & - & - \\
\hline MTR & Triticale & & & & & & & & \\
\hline & Azevém & 03,8 & 07,3 & 13,6 & 27,7 & 52,0 & 77,1 & 92,8 & 100,0 \\
\hline & Ryegrass & & & & & & & & \\
\hline MCA & Centeio & 30,3 & 51,0 & 62,8 & 78,3 & 94,3 & 99,3 & 100,0 & - \\
\hline$M R R$ & Rye & & & & & & & & \\
\hline & $\begin{array}{l}\text { Azevém } \\
\text { Ryegrass }\end{array}$ & 02,2 & 03,2 & 05,1 & 12,7 & 33,1 & 64,1 & 88,2 & 100,0 \\
\hline
\end{tabular}

Tabela 3 - Componentes botânicos (\%) dos resíduos, em pastagens de misturas de gramíneas anuais de estação fria nos diferentes períodos de avaliação

Table 3 - Sward botanical composition of the residuals throughout the experimental period in annual temperate grasses mixtures pastures

\begin{tabular}{|c|c|c|c|c|c|c|c|c|c|}
\hline \multirow{3}{*}{$\begin{array}{l}\text { Componente } \\
\text { Component }\end{array}$} & \multicolumn{9}{|c|}{$\begin{array}{c}\text { Data da avaliação } \\
\text { Evaluation date }\end{array}$} \\
\hline & $21 / 05$ & $18 / 06$ & $13 / 07$ & $10 / 08$ & $07 / 09$ & $06 / 10$ & $03 / 11$ & $19 / 11$ & Média \\
\hline & $05 / 21$ & $06 / 18$ & $07 / 13$ & $08 / 10$ & $09 / 07$ & $10 / 06$ & $11 / 03$ & $11 / 19$ & Mean \\
\hline Aveia & $83,3^{a^{*}}$ & $75,7^{b}$ & $43,4^{\mathrm{c}}$ & $16,6^{\mathrm{d}}$ & $08,7^{\mathrm{e}}$ & - & - & - & 28,4 \\
\hline Oat & $16,7^{\mathrm{e}}$ & $15,5^{\mathrm{e}}$ & $32,4^{\mathrm{d}}$ & $52,00^{\mathrm{c}}$ & $68,1^{\mathrm{a}}$ & $64,6^{\mathrm{ab}}$ & $70,9^{\mathrm{a}}$ & $54,6^{\mathrm{bc}}$ & 46,9 \\
\hline $\begin{array}{l}\text { Ryegrass } \\
\text { M. Morto } \\
\text { Death M. }\end{array}$ & - & $08,8^{d}$ & $24,2^{b c}$ & $31,4^{\mathrm{bc}}$ & $23,2^{\mathrm{c}}$ & $35,4^{\mathrm{ab}}$ & $29,1^{b}$ & $45,4^{\mathrm{a}}$ & 24,7 \\
\hline $\begin{array}{l}\text { Triticale } \\
\text { Triticale }\end{array}$ & $75,3^{\mathrm{a}}$ & $63,7^{b}$ & $47,0^{\mathrm{c}}$ & $25,1^{\mathrm{d}}$ & $10,5^{\mathrm{e}}$ & - & - & - & 27,7 \\
\hline $\begin{array}{l}\text { Azevém } \\
\text { Ryegrass }\end{array}$ & $24,7^{\mathrm{e}}$ & $22,0^{e}$ & $39,5^{\mathrm{d}}$ & $57,4^{\mathrm{bc}}$ & $72,4^{\mathrm{a}}$ & $64,6^{\mathrm{ab}}$ & $66,4^{\mathrm{ab}}$ & $51,5^{\mathrm{c}}$ & 49,8 \\
\hline $\begin{array}{l}\text { M. Morto } \\
\text { Death M. }\end{array}$ & & $14,3^{c}$ & $14,5^{\mathrm{c}}$ & $17,5^{\mathrm{c}}$ & $17,1^{\mathrm{c}}$ & $35,4^{\mathrm{b}}$ & $33,6^{\mathrm{b}}$ & $48,5^{\mathrm{a}}$ & 22,5 \\
\hline $\begin{array}{l}\text { Centeio } \\
\text { Rye }\end{array}$ & $91,5^{\mathrm{a}}$ & $68,6^{\mathrm{b}}$ & $32,5^{\mathrm{c}}$ & $33,4^{\mathrm{c}}$ & $18,5^{\mathrm{d}}$ & $03,7^{\mathrm{e}}$ & - & - & 31,0 \\
\hline Azevém & $08,5^{\mathrm{d}}$ & $05,0^{\mathrm{d}}$ & $14,2^{\mathrm{d}}$ & $33,9^{\mathrm{c}}$ & $54,5^{\mathrm{b}}$ & $59,8^{\mathrm{ab}}$ & $68,6^{\mathrm{a}}$ & $62,0^{\mathrm{ab}}$ & 38,3 \\
\hline $\begin{array}{l}\text { M. Morto } \\
\text { Death M. }\end{array}$ & - & $26,4^{b}$ & $53,3^{\mathrm{a}}$ & $32,7^{\mathrm{b}}$ & $27,0^{\mathrm{b}}$ & $36,5^{\mathrm{b}}$ & $31,4^{\mathrm{b}}$ & $38,0^{\mathrm{b}}$ & 30,7 \\
\hline
\end{tabular}

acamamento de plantas nas misturas com aveia preta e centeio. Com base nisto, optou-se pelo início do pastejo nestas duas misturas, 14 dias mais cedo que na MTA. Os baixos resíduos iniciais são decorrentes, principalmente, dos baixos teores de MS presente na forragem, mesmo tendo apresentado grande quantidade de forragem verde.

A porcentagem de MS da massa de forragem encontra-se na Tabela 5. Houve interação significa- tiva entre mistura e período de pastejo para esta variável. Analisando as misturas por período, observa-se diferença significativa entre as misturas na maioria dos períodos de pastejo. As diferenças encontradas no percentual de MS nos períodos iniciais de utilização da pastagem estão basicamente ligadas às espécies formadoras das misturas. Já nos períodos finais, as diferenças estão associadas à massa de forragem da pastagem, em que os maiores percentuais 
Rev. bras. zootec.

Tabela 4 - Massa de forragem (kg de MS/ha) em pastagem com misturas de gramíneas anuais de estação fria nas diferentes datas de avaliações

Table 4 - Herbage mass ( $\mathrm{kg}$ of $\mathrm{DM} / \mathrm{ha}$ ) in annual temperate grasses mixtures pastures throughout the experimental period

\begin{tabular}{|c|c|c|c|c|c|c|c|c|c|}
\hline \multirow{3}{*}{$\begin{array}{l}\text { Trat. } \\
\text { Treat. }\end{array}$} & \multicolumn{9}{|c|}{$\begin{array}{c}\text { Data de avaliação } \\
\text { Evaluation date }\end{array}$} \\
\hline & $21 / 05$ & $18 / 06$ & $16 / 07$ & $13 / 08$ & $10 / 09$ & $08 / 10$ & $05 / 11$ & $19 / 11$ & Média \\
\hline & $05 / 21$ & $06 / 18$ & $07 / 16$ & $08 / 13$ & $09 / 10$ & $10 / 08$ & $11 / 05$ & $11 / 19$ & Mean \\
\hline MAA & 1020 & 1284 & 1139 & 1462 & 1821 & 1574 & 1606 & 1093 & 1426 \\
\hline$M O R$ & & & & & & & & & \\
\hline MTA & 0994 & 1662 & 1388 & 1709 & 2040 & 1750 & 1646 & 1077 & 1623 \\
\hline$M T R$ & & & & & & & & & \\
\hline $\begin{array}{l}\mathrm{MCA} \\
M R R\end{array}$ & 1412 & 1550 & 0993 & 1349 & 1914 & 1587 & 1761 & 1341 & 1501 \\
\hline $\begin{array}{l}\text { Média } \\
\text { Mean }\end{array}$ & 1142 & 1499 & 1173 & 1506 & 1925 & 1638 & 1671 & 1169 & \\
\hline
\end{tabular}

Tabela 5 - Porcentagem de MS, DIVMO e proteína bruta (PB) do resíduo na pastagem com mistura de gramíneas anuais de estação fria nos períodos de avaliações

Table 5 - Percentage of DM, IVOMD and crude protein (CP) of the residue in annual temperate grasses mixtures pastures throughout the experimental period

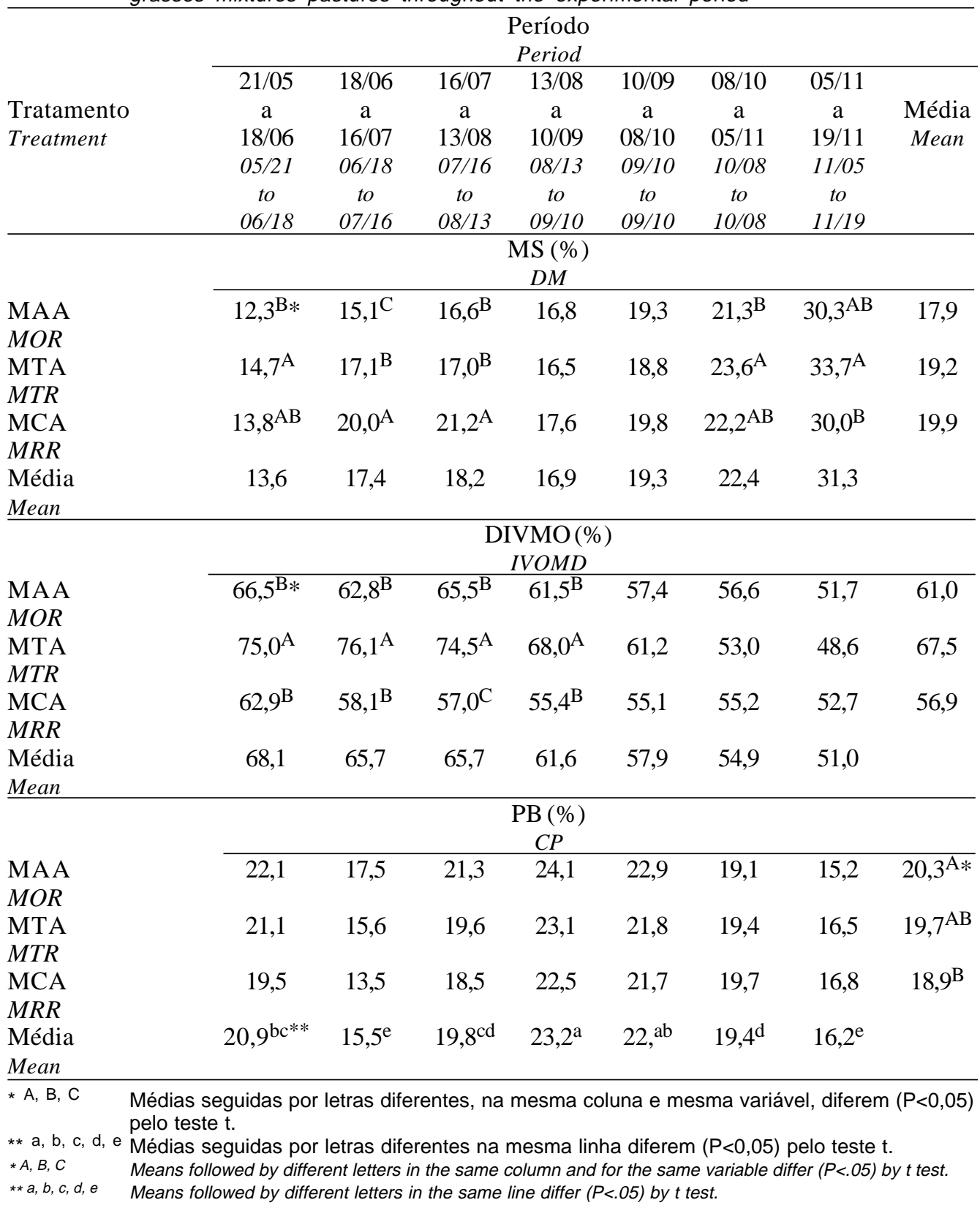


de MS foram encontrados nas menores massas de forragem sendo então, consequência do manejo. A diferença no percentual de MS da forragem disponível foi um dos principais fatores responsáveis pelas diferença obtidas nos resíduos, pois, no momento do ajuste da carga animal, estimou-se teor de MS semelhante para as misturas, mas não foi o que realmente ocorreu.

A DIVMO média da forragem disponível encontra-se na Tabela 5. Houve interação significativa entre mistura e período de pastejo. Observa-se que, nos quatro primeiros períodos (21/05 a 10/09), quando existiu diferença no percentual dos componentes entre as misturas, houve diferença significativa na DIVMO entre as misturas. Já nos demais períodos (10/09 a 19/11), quando não houve grandes diferenças entre as misturas quanto aos seus componentes botânicos, não foram observadas diferenças na DIVMO, pois as misturas foram formadas basicamente por azevém.

$\mathrm{Na}$ maioria dos períodos, a MTA apresentou DIVMO superior às demais, devido, basicamente, ao maior percentual de azevém presente nas avaliações iniciais desta mistura (Tabela 3). O azevém apresentou DIVMO maior que as demais espécies e o triticale, maior DIVMO que os demais componentes das misturas (Tabela 6). Entretanto, ROSO et al. (1999) não encontram diferença na DIVMO, nos primeiros períodos de pastejo, em misturas de aveia e azevém, nem de triticale e azevém.

A redução no valor nutritivo da forragem, com o avanço no ciclo de desenvolvimento das plantas, é explicado pelo aumento da parede celular (BLASER, 1964), pela redução na relação folha/caule e pelo aumento no percentual de material morto.

A proteína bruta média da forragem disponível encontra-se na Tabela 5. Não houve interação significativa entre tratamento e período de pastejo para esta variável. Na média das três misturas, ocorreu decréscimo significativo do primeiro (21/05 a 18/06) para o segundo período (18/06 a 16/07), aumentando até o quarto período, o qual apresentou o valor máximo $(23,3 \%)$, decrescendo novamente até o final do período de utilização da pastagem.

Na média do período experimental, houve diferença entre as misturas, sendo o maior teor de proteína bruta obtido na MAA e o menor teor, na MCA; já a MTA apresentou valores semelhantes às demais misturas. Provavelmente, a diferença no teor de PB está ligada ao teor de PB dos componentes botânicos presentes na massa de forragem das misturas. ROSO et al. (1998), entretanto, obtiveram resultados superiores para a mistura de aveia + azevém em relação à triticale + azevém.

Os resultados obtidos neste experimento foram superiores aos obtidos por ROSO et al. (1999), em misturas semelhantes; RESTLEet al. (1998), em misturas de aveia preta + azevém; LUPATINI et al. (1998), no nível de $150 \mathrm{~kg}$ de N/ha; e QUADROS e MARASCHIN (1987) e LESAMA (1997), em misturas de gramíneas + leguminosas, mostrando que nestas misturas não há necessidade de inclusão de leguminosas.

Os valores médios da DIVMO dos componentes botânicos das misturas são apresentados na Tabela 6. A análise dos dados da primeira avaliação (21/05) não evidenciou diferença significativa entre os componentes formadores das misturas, apesar dos mais baixos valores observados para a aveia e o centeio. Os valores variaram de 65,4 a 74,6\% de DIVMO. Já na segunda avaliação (18/06), não houve diferença significativa entre os componentes botânicos da MAA e MTA, diferindo significativamente dos componentes botânicos da MCA, que apresentaram os menores valores de DIVMO, com exceção do material morto, que foi semelhante entre as misturas. Na terceira avaliação (16/07), a maior DIVMO correspondeu ao componente azevém da mistura com centeio, não diferindo dos demais azevém e triticale. O centeio apresentou DIVMO intermediária, sendo semelhante ao triticale e à aveia, que apresentaram a menor DIVMO. Na quarta avaliação (13/08), a maior DIVMO foi obtida no componente azevém das misturas com aveia preta e triticale e no componente triticale, diferindo $(\mathrm{P}<0,05)$ dos demais componentes. Na quinta avaliação (10/09), os componentes azevém das misturas com aveia preta e triticale apresentaram a maior DIVMO, diferindo significativamente dos componentes aveia preta, triticale e centeio, que se encontravam em final de ciclo produtivo, sendo que destes a aveia apresentou a maior DIVMO.

O teor de PB médio dos componentes botânicos das misturas por avaliação encontra-se na Tabela 6 . Analisando os dados por avaliação, verifica-se que os teores de PB na primeira avaliação $(21 / 05)$ de aveia preta, triticale e centeio apresentaram teor de PB elevado e não diferiram entre si. Já na segunda avaliação (18/06), o centeio apresentou o menor teor de $\mathrm{PB}$, diferindo significativamente dos demais componentes, que não diferiram entre si. Na terceira avaliação (16/07), o azevém da mistura com centeio apresentou o maior teor de proteína bruta, diferindo significativamente dos demais azevém, que apresentaram valores superiores aos demais componentes. $\mathrm{O}$ centeio apresentou teor de PB superior ao da aveia 
Rev. bras. zootec.

Tabela 6 - Digestibilidade in vitro da matéria orgânica (DIVMO) e teor de proteína bruta (CP) dos componentes botânicos dos resíduos

Table 6 - In vitro organic matter digestibility (IVOMD) and crude protein (CP) content of the botanical components of the residuals

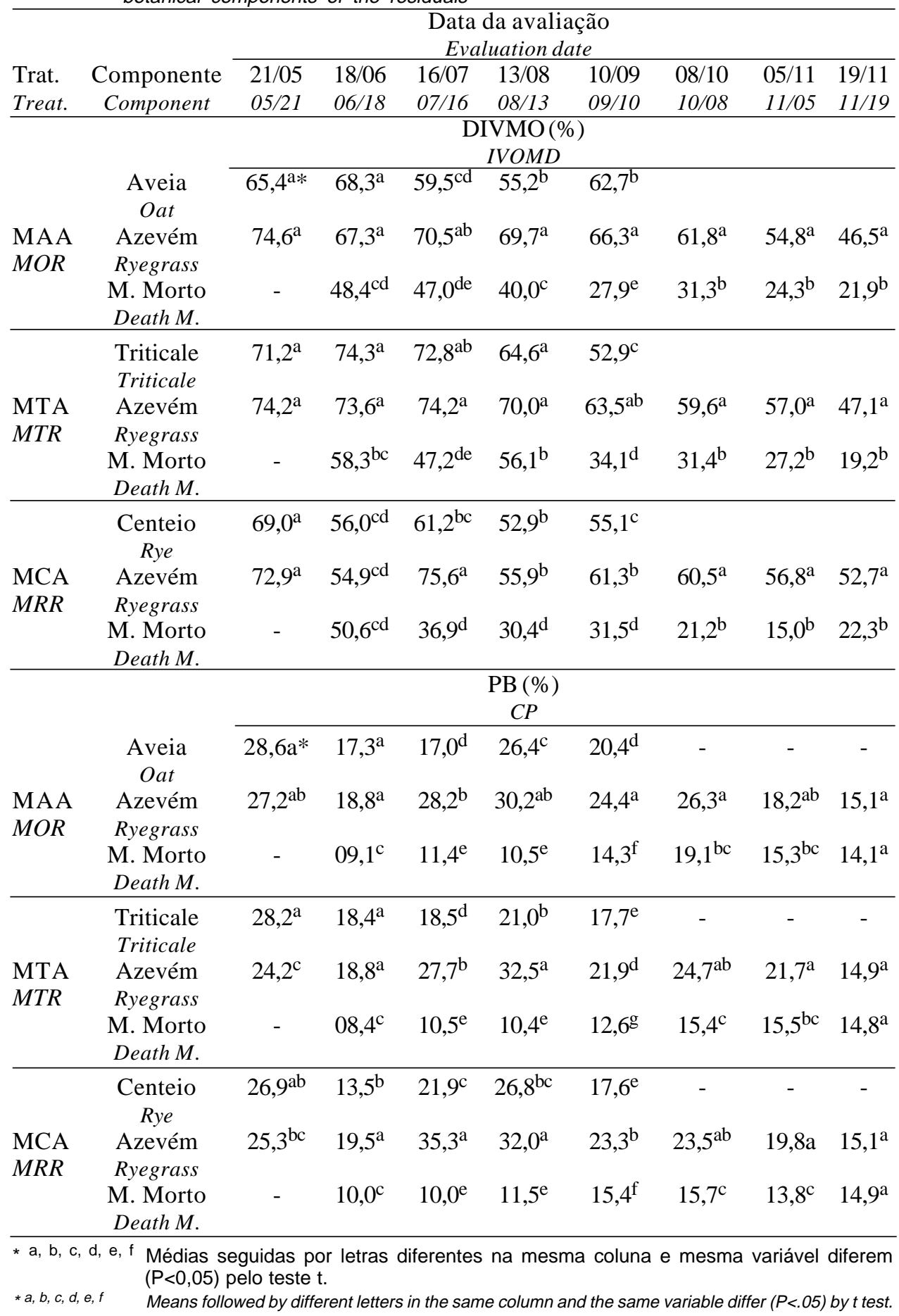

preta e triticale, principalmente por serem plantas originadas de afilhos ocorridos após o espigamento. Na quarta avaliação (13/08), o azevém de todas as misturas apresentou teor de PB superior aos demais componentes, sendo que o triticale apresentou teor de $\mathrm{PB}$ inferior ao da aveia preta e centeio. Na quinta avaliação (10/09), houve diferença significativa entre os azevém das diferentes misturas, sendo que o azevém da mistura com aveia preta apresentou maior teor de PB, seguido pelo azevém da mistura com centeio e triticale. O componente aveia apresentou maior teor de PB que o triticale e o centeio, que não diferiram entre si. Nas demais avaliações, houve somente participação azevém. 


\section{Conclusões}

As misturas apresentaram taxa de acúmulo diário e produção total de matéria seca semelhantes.

Maior produção de forragem logo após o estabelecimento foi apresentada pela mistura de centeio mais azevém.

A mistura de aveia preta mais azevém apresentou maior produção de forragem nos períodos iniciais de pastejo.

A mistura de triticale mais azevém apresentou melhor distribuição da produção de forragem ao longo do período de pastejo.

O triticale permitiu melhor desenvolvimento inicial do azevém.

O triticale apresentou maior DIVMO, seguido pela aveia preta e centeio, os quais, entretanto, apresentara conteúdo de proteína bruta semelhantes.

A aveia preta, o triticale e o centeio, devido ao seu rápido crescimento inicial, apresentaram excelente potencial para utilização precoce das pastagens e, em associação com o azevém, apresentaram longo período de utilização, com elevada produção e qualidade de forragem.

\section{Referências Bibliográficas}

ASSOCIATION OF OFFICIAL ANALYTICAL CHEMISTS AOAC. 1984. Official methods of analysis. $14 \mathrm{ed}$. Washington. $1141 \mathrm{p}$.

BAIER, A.C. Centeio. Passo Fundo: EMBRAPA-CNPT, 1994. 29p. (EMBRAPA-CNPT. Documentos, 15).

BAIER, A.C., NEDEL, J.L., REIS, E.M. et al. 1994. Triticale: cultivo e aproveitamento. Passo Fundo: EMBRAPA-CNPT. 72p. (EMBRAPA-CNPT. Documentos, 19).

BAIER, A.C., 1989. Triticale. In: BAIER, A.C., AUDE, M.I.S., FLOSS, E.L. As lavouras de inverno-1. São Paulo: Globo. p.76-106.

BLASER, R.E. 1964. Symposium on forage utilization: Effects of fertility levels and stage of maturity on forage nutritive value. J. Anim. Sci., 23:246-253.

CAMPBELL, A.G. 1966. Grazed pastures parameters. I. Pasture dry matter production and availability in a stocking rate and grazing management experiment with dairy cows. J. Agric. Sci., 67:211-216.

FONTANELI, R.S., FONTANELI, S.S., SILVA, G. da. 1996. Avaliação de cereais de inverno para duplo propósito. Pesq. Agropec. Bras., 31(1):43-50.

IBGE. 1996. Instituto Brasileiro de Geografia e Estatística. Anuário Estatístico do Brasil, Rio de Janeiro, v.56.

LEMAIRE, G. The phisiology of grass growth under grazing: Tissue turn-over. SIMPÓSIO INTERNACIONAL SOBRE PRODUÇÃO ANIMAL EM PASTEJO, Viçosa, 1997. Anais... Viçosa: UFV/DZO, 1997. p.117-144.

LESAMA, M.F. Produção animal em gramíneas de estação fria comfertilização nitrogenada ou associadas com leguminosa, com ou sem fertilização nitrogenada. Santa Maria: UFSM,
1997. 129p. Dissertação (Mestrado em Zootecnia) - Universidade Federal de Santa Maria, 1997.

LUPATINI, G.C., RESTlE, J., CERETTA, M. et al. 1998. Avaliação da mistura de aveia preta e azevém sob pastejo submetida a níveis de nitrogênio. Pesq. Agropec. Bras., 33(11):1939-1943.

MORENO, J.A. 1961. Clima do Rio Grande do Sul. Porto Alegre: Secretaria da Agricultura. 41p.

MOTT, G.O., LUCAS, H.L. 1952. The design conduct and interpretation of grazing trials on cultivated and improved pastures. In: INTERNATIONAL GRASSLAND CONGRESS, 6, 1952. Proceedings... Pensylvania, State College Press., p.1380-1395.

QUADROS, F.L.F., MARASCHIN, G.E. 1987. Desempenho animal em misturas de espécies forrageiras de estação fria. Pesq. Agropec. Bras., 22(5):535-541.

RECOMENDAÇÕES DE ADUBAÇÃO E CALAGEM PARA OS ESTADOS DO RIO GRANDE DO SUL E SANTA CATARINA. 1989. 2. ed. Passo Fundo: SBCS, Núcleo Regional Sul - EMBRAPA- CNPT. 128p.

RESTLE, J., LUPATINI, G.C., ROSO, C. et al. 1998. Eficiência e desempenho de diferentes categorias de bovinos de corte em pastagem cultivada. R.. Bras. Zootec., 27(2):397-404.

RESTLE, J., ROSO, C., SOARES, A.B. Dinâmica de uma pastagem de aveia preta (Avena strigosa) e azevém (Lolium multiflorum) submetida a fontes de nitrogênio. In: REUNIÃO ANUAL DA SOCIEDADE BRASILEIRA DE ZOOTECNIA, 34, 1997, Juiz de Fora. Anais... Viçosa: SBZ. 1997. p.179-181.

ROSO, C., RESTLE, J., SOARES, A.B. 1999. Produção e qualidade de forragem da mistura de gramíneas anuais de estação fria sob pastejo contínuo. Rev. bras. zootec., 28(3):459-467.

SÁ, J.P.G., OLIVEIRA, J.C. Avaliação de forrageiras de inverno em Londrina, Paraná. In: REUNIÃO ANUAL DA SOCIEDADE BRASILEIRA DE ZOOTECNIA, 32, 1995, Brasília. Anais... Viçosa: SBZ, 1995. p.18-19.

SAS. 1990. Institute Inc. SAS Language reference. Version 6, Cary, NC: SAS Institute Inc. 1042p.

TILLEY, J.M.A., TERRY, R.A. 1963. A two-stage technique for the in vitro digestion of forage crop. J. Brit. Grassland Soc., 18(2):104-111.

Recebido em: 02/02/99

Aceito em: 21/07/99 